\title{
The role of plasmid genes in the pathogenicity of Salmonella dublin
}

\author{
E. JANE MANNING*, G. D. BAIRD and P. W. JONES
}

\author{
AFRC Institute for Research on Animal Diseases, Compton, Berks RG16 ONN
}

\begin{abstract}
Summary. The virulence (expressed as LD50 values) for mice of two mutant strains of Salmonella dublin, both containing $\operatorname{Tn} A$ insertions in the resident plasmid, was reduced by $10^{4}-10^{5}$ when infection was by the oral or intravenous or intraperitoneal route. When the plasmid was lost from one of the mutants no further decrease in virulence was observed. Results also suggested that plasmid genes are not involved in the ability of $S$. dublin to cross the gut wall.
\end{abstract}

\section{Introduction}

Plasmids play a role in the pathogenicity of Salmonella typhimurium (Jones et al., 1982) and $S$. dublin (Terakado et al., 1983). Jones and his colleagues also showed that a plasmid in $S$. typhimurium was essential for adhesion to, and invasion of, HeLa cells (Jones et al., 1982). The role in pathogenicity of the $S$. dublin plasmid has not been identified.

This paper describes two mutant strains of $S$. dublin which have substantially lost virulence through a single transposon insertion in the resident plasmid (mol. wt $46 \times 10^{6}$ ). The derivation of these strains from the wild type and the plasmid DNA of the wild-type and mutant strains are described in detail by Baird and Manning (1984). In this study, a comparison has been made of the behaviour of the parent and mutant strains in virulence experiments in mice in the hope of identifying the role of the plasmid in pathogenicity. Some results have been published in preliminary form (Manning et al., 1984).

\section{Materials and methods}

\section{Bacterial strains.}

$S$. dublin strain 2229 was smooth, aerogenic and virulent for mice and calves. It was isolated from an outbreak of calf enteritis in Britain in 1979. The mutants also used in this study (strains M51 and M173) were transposon-insertion mutants of strain 2229. In each there was a single insertion of transposon $\operatorname{Tn} A$ in the serotype-specific plasmid (mol. wt $\left.46 \times 10^{6}\right)$; in the case of

Received 31 May 1985; accepted 4 Aug. 1985.

* Correspondence should be addressed to: Dr E. J. Manning, Department of Paediatrics, John Radcliffe Hospital, Headington, Oxford OX3 9DU. strain M51, the transposition event resulted in the deletion of a segment of DNA of c. 3 kilobase-pairs (Baird and Manning, 1984). Strain 173/2 was a cured derivative of mutant M173 without the $46 \times 10^{6}$-mol. wt plasmid (see below). Escherichia coli K12 strain 14R525, a plasmid-free, serum-sensitive laboratory strain was kindly supplied by Dr H. R. Smith (P.H.L.S., Colindale, London).

\section{Curing of plasmid DNA}

Mutant M173, whose plasmid contained $\operatorname{Tn} A$ encoding ampicillin resistance, was grown overnight in LuriaBertani (LB) broth containing the curing agent ethidium bromide $10 \mu \mathrm{g} / \mathrm{ml}$. To enrich for ampicillin sensitivity (indicating possible loss of the plasmid) the method of Rodriguez et al. (1976) was adopted. One $\mathrm{ml}$ of the overnight broth culture was subcultured into $100 \mathrm{ml}$ of fresh $\mathrm{LB}$ broth and incubated at $37^{\circ} \mathrm{C}$ for $1 \mathrm{~h}$. Ampicillin was added to a final concentration of $500 \mu \mathrm{g} / \mathrm{ml}$, and the culture incubated at $37^{\circ} \mathrm{C}$ for a further $45 \mathrm{~min}$. Cycloserine, which in this situation kills only actively growing, ampicillin-resistant bacteria, was then added to a final concentration of $100 \mu \mathrm{g} / \mathrm{ml}$. After incubation at $37^{\circ} \mathrm{C}$ for another $2.5 \mathrm{~h}, 100-\mu \mathrm{l}$ portions of undiluted culture and of a 1 in 10 dilution were spread on LB agar plates which were incubated overnight at $37^{\circ} \mathrm{C}$. Each plate was then replica-plated on to LB agar plates containing ampicillin $500 \mu \mathrm{g} / \mathrm{ml}$ and ampicillin-sensitive colonies were sought. Only one ampicillin-sensitive $\left(\mathrm{Amp}^{\mathrm{s}}\right)$ derivative was identified in a total of $c .25000$ colonies examined. This derivative, designated $173 / 2$, was serologically and biochemically identical to $S$. dublin strain M173. Plasmid analysis (see below) showed that it lacked the plasmid of mol. wt $46 \times 10^{6}$.

\section{Viable counts}

Bacterial counts were determined in inocula and in other samples by making serial ten-fold dilutions of the samples in saline and spreading $0.1 \mathrm{ml}$ of appropriate dilutions on LB agar plates. The number of $\mathrm{cfu} / \mathrm{ml}$ or $/ \mathrm{g}$ was calculated. 


\section{Virulence testing}

The virulence of each bacterial strain was tested in C57 $\mathrm{BL} / \mathrm{COM}$ mice, except in two experiments in which Lac/ $\mathrm{G} / \mathrm{COM}$ mice were used. Strains were grown in LB broth at $37^{\circ} \mathrm{C}$ for $16 \mathrm{~h}$. Dilutions were made in saline and administered orally to groups of eight mice $(0.1 \mathrm{ml} /$ mouse). Deaths were monitored up to 14 days and LD50 values calculated by the method of Reed and Muench (1938). The number of organisms administered to each animal was calculated from viable counts of the inocula. In some experiments the challenge doses were injected into the mice by the intraperitoneal (ip) or intravenous (iv) (tail vein) route $(0.1 \mathrm{ml} / \mathrm{mouse})$.

\section{Counts of bacteria in spleens}

The appropriate dilution (determined from preliminary experiments) of an overnight broth culture of each test strain was given by mouth to groups of C57BL/COM mice $(0.1 \mathrm{ml} /$ mouse). At various times after administration, spleens, usually from groups of four mice, were removed, pooled and weighed. Saline $(9 \mathrm{ml} / \mathrm{g}$ of tissue) was added and samples were homogenised in Griffith's tubes. Appropriate dilutions of the homogenates were spread on LB agar plates for the determination of viable counts.

\section{Plasmid analysis}

Plasmids were extracted by the method of Birnboim and Doly (1979), and analysed by electrophoresis in $0.6 \%$ agarose gels run horizontally at $100 \mathrm{~V}$ for $5 \mathrm{~h}$, in a Trisacetate buffer system (Tris $4.48 \mathrm{~g}$, sodium acetate $0.68 \mathrm{~g}$, EDTA $1.49 \mathrm{~g}$, in $1 \mathrm{~L}, p \mathrm{H} \mathrm{7.8)}$. Plasmid bands were visualised by immersing the gel in ethidium bromide $50 \mu \mathrm{g} / \mathrm{ml}$ for $1-16 \mathrm{~h}$.

\section{Serum resistance determination}

Serum resistance was assayed by the method of Taylor et al. (1972). Overnight broth cultures of each test organism were subcultured into fresh LB broth $(0.5 \mathrm{ml}$ into $10 \mathrm{ml}$ ) and grown to an $\mathrm{OD}_{650}$ of 0.5 . A ten-fold dilution was then made to give a concentration of c. $2 \times 10^{7}$ bacteria/ml, and $0.5-\mathrm{ml}$ portions of this suspension were added to various dilutions (in saline) of rabbit or bovine serum, to give a final assay volume of $2.5 \mathrm{ml}$. Samples were incubated at $37^{\circ} \mathrm{C}$ for $90 \mathrm{~min}$. Appropriate dilutions of each sample were prepared and viable counts determined at times 0 and $90 \mathrm{~min}$.

\section{Haemagglutinin assays}

Mannose-resistant and mannose-sensitive haemagglutinins were assayed by the microhaemagglutination method of Jones and Rutter (1974).

\section{Results}

\section{LD50 values after oral administration}

The oral LD50 value of strain 2229 was $10^{4}-10^{5}$ less than that of strains M173 (table I; see also Baird and Manning, 1984) and M51 (table I). The virulence of the cured derivative (173/2) of strain M173 (fig. 1) was low in mice, similar to that of strain M173 itself (table I).

\section{Invasiveness of wild-type and mutant strains}

The invasiveness of the $S$. dublin strains, expressed as the ability of the bacteria to cross the gut wall and accumulate in various tissues after oral administration, was assessed because several recent reports have described virulence plasmids that confer invasive properties upon $S$. typhimurium (Jones et al., 1982) and Shigella spp. (Hale et al., 1983). For a given dose, the accumulation of strain M5l in spleen was lower than that of the parent strain 2229(fig. 2A). After administration of a lethal dose of strain 2229, counts in spleen tissue reached $10^{7}-10^{8}$ $\mathrm{cfu} /$ spleen by the time of death (day 4) (fig. 2A). After a dose of $c .1$ LD50 of strain M51, bacteria accumulated to high counts in the spleen by day 7 , but then counts dropped substantially (fig. 2B). This can probably be explained by the fact that each sample was a pool of four spleens and approximately half of the animals given this dose would be expected to die, therefore each pooled sample (up to day 10) would contain two spleens from mice that would have died and two from mice that would have survived. However no mice died after day 10 , therefore all spleens taken from day 10 onwards would have been from mice that survived the challenge, and would have lower bacterial counts in

Table I. Virulence of $S$. dublin strain 2229, two mutant strains (M51 and M173) and a cured derivative (173/2)

\begin{tabular}{|c|c|c|c|c|c|}
\hline \multirow{2}{*}{$\begin{array}{l}\text { Mouse } \\
\text { strain }\end{array}$} & \multirow{2}{*}{$\begin{array}{c}\text { Route of } \\
\text { inoculation }\end{array}$} & \multicolumn{4}{|c|}{$\log _{10}$ LD50* $^{*}$ of strain } \\
\hline & & 2229 & M51 & M173 & $173 / 2$ \\
\hline C57BL/COM & oral & $2 \cdot 7$ & $7 \cdot 7$ & NT & NT \\
\hline C57BL/COM & oral & $2 \cdot 8$ & NT & $7 \cdot 1$ & NT \\
\hline C57BL/COM & oral & $2 \cdot 9$ & 6.9 & $8 \cdot 2$ & $7 \cdot 8$ \\
\hline $\mathrm{Lac} / \mathrm{G} / \mathrm{COM}$ & oral & $2 \cdot 8$ & $7 \cdot 3$ & $>6.8$ & NT \\
\hline C57BL/COM & ip & $<0.8$ & $>4.8$ & $>4.2$ & NT \\
\hline C57BL/COM & ip & $<0.8$ & 5.9 & $5 \cdot 2$ & 5.9 \\
\hline $\mathrm{Lac} / \mathrm{G} / \mathrm{COM}$ & iv & $<0.7$ & $4 \cdot 7$ & $5 \cdot 2$ & $5 \cdot 2$ \\
\hline
\end{tabular}

NT $=$ Not tested.

* LD50 values are expressed as cfu/mouse. 


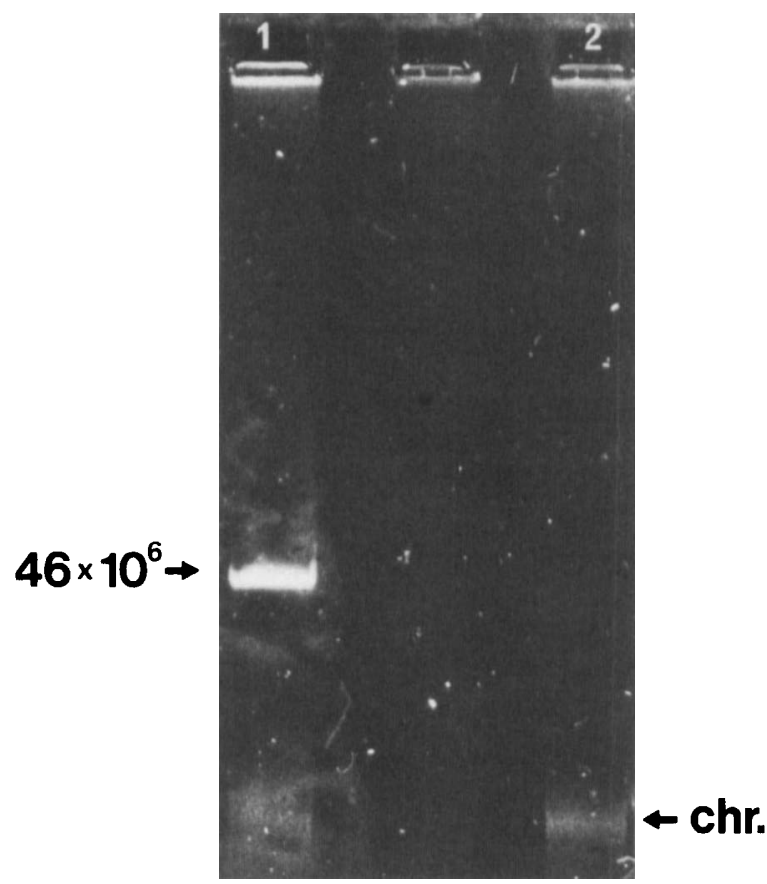

Fig. 1. Plasmid profiles of $S$. dublin strains obtained by electrophoresis of extracts in agarose gel; mutant M173 is in lane 1 and cured derivative $173 / 2$ in lane 2 . The $46 \times 10^{6}-\mathrm{mol}$. wt plasmid and contaminating chromosomal DNA (chr.) are indicated.

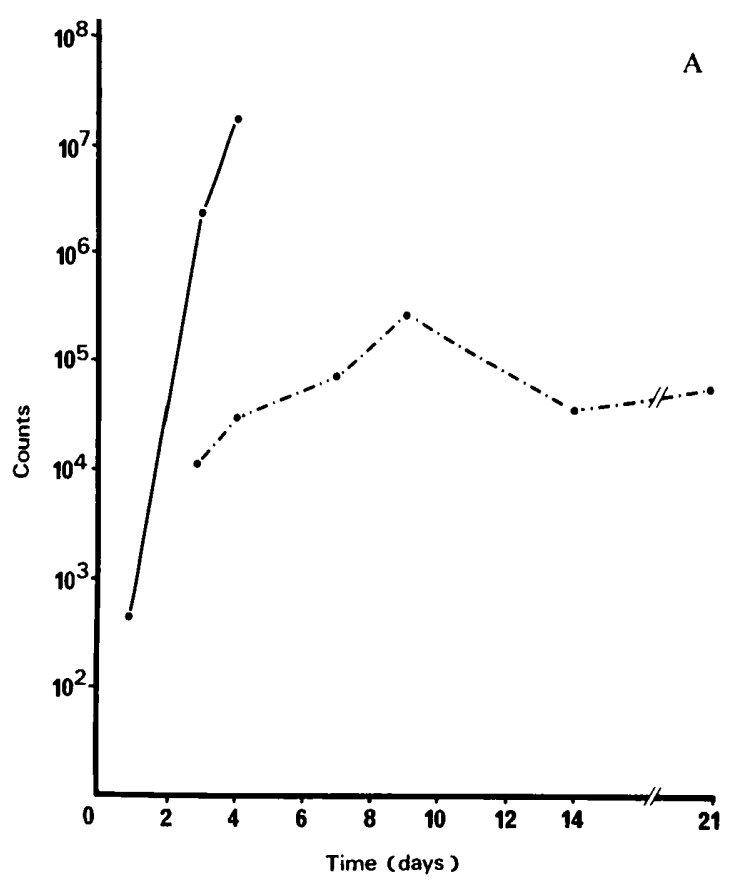

their spleens after that time. Similar results were obtained with strain M173 (results not shown). The accumulation of both mutants in the spleens of mice showed that each could still invade across the gut mucosa. However, these results did not show whether invasion by the mutant strains was as efficient as that of the wild type.

\section{Haemagglutinin production}

Adhesion to, and invasion of, HeLa cells by $S$. typhimurium depends upon a mannose-resistant haemagglutinin (MRHA) (Jones and Richardson, 1981). Therefore we assayed MRHA and also mannose-sensitive haemagglutinins (MSHA) in strain 2229, mutants M51 and M173, and the cured derivative 173/2. MSHA was detected in each strain but MRHA was not, indicating that MRHA is not involved in the virulence of $S$. dublin strain 2229 and

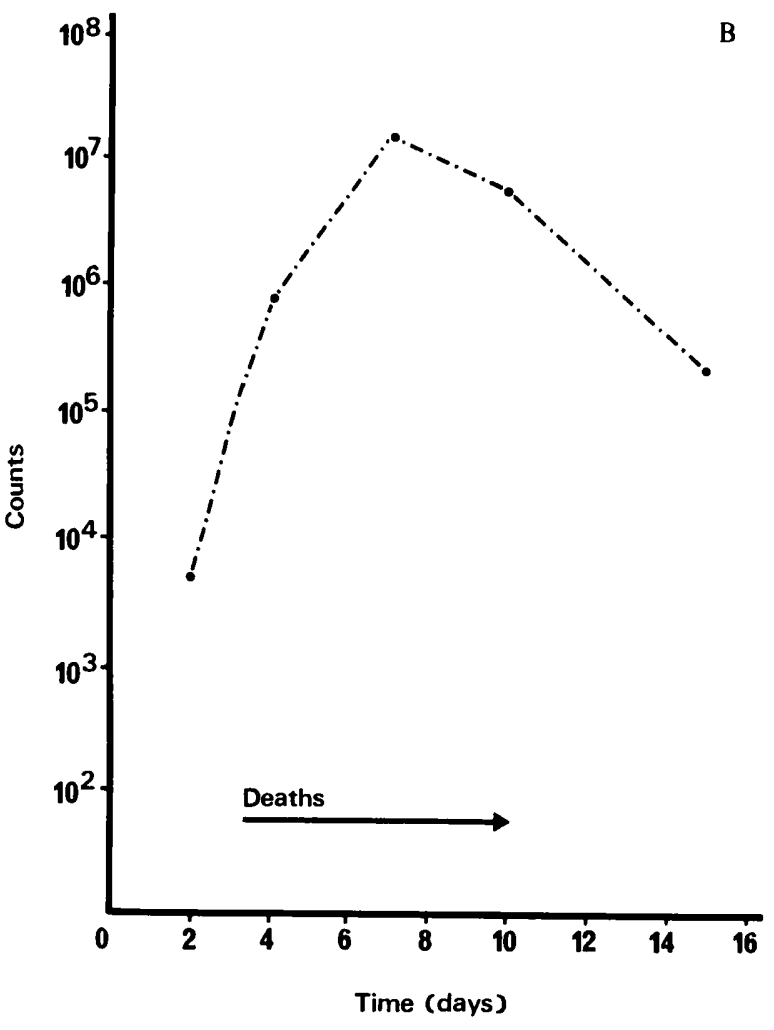

Fig. 2. The accumulation of S. dublin strains $2229(\bullet-\infty)$ and M51 (-.-- $)$ in mouse spleens after oral inoculation. (A). Dose of strain 2229 was $6 \times 10^{5} \mathrm{cfu} /$ mouse; mice did not survive after day 4. Dose of strain M51 was $5 \times 10^{5} \mathrm{cfu} /$ mouse; all mice survived. (B). Dose of strain M51 was $3 \times 10^{7} \mathrm{cfu} /$ mouse (LD50 dose); $50 \%$ of mice survived. The arrow indicates the period during which mice died. After day 10 all surviving mice remained healthy. 
Table II. The survival of $S$. dublin strains in normal rabbit and bovine serum

\begin{tabular}{|c|c|c|c|c|c|c|}
\hline \multirow{2}{*}{$\begin{array}{l}\text { Source } \\
\text { of serum }\end{array}$} & \multirow{2}{*}{$\begin{array}{l}\text { Final } \\
\text { concentration } \\
\text { of serum } \\
(\%)\end{array}$} & \multicolumn{5}{|c|}{$\begin{array}{l}\text { Percentage survival after } \\
90 \mathrm{~min}^{*} \text { of strain }\end{array}$} \\
\hline & & 2229 & M5I & M173 & $173 / 2$ & 14R525† \\
\hline \multirow{6}{*}{ Rabbit } & 0 & 329 & 322 & 324 & NT & 470 \\
\hline & 5 & 722 & 306 & 333 & NT & 0.3 \\
\hline & 10 & 271 & 238 & 300 & NT & $1 \times 10^{-4}$ \\
\hline & 20 & 277 & 307 & 336 & NT & $2 \times 10^{-4}$ \\
\hline & 40 & 417 & 384 & 360 & NT & $<1 \times 10^{-4}$ \\
\hline & 80 & 370 & 311 & 260 & NT & $<1 \times 10^{4}$ \\
\hline \multirow{2}{*}{ Bovine } & 0 & 182 & 167 & 242 & 200 & 320 \\
\hline & 80 & 29 & 34 & 17 & 34 & $<1 \times 10^{-4}$ \\
\hline
\end{tabular}

NT $=$ Not tested.

† Strain 14R525 was a plasmid-free serum-sensitive laboratory strain of E. coli.

* Percentage survival $=\frac{\text { Number of bacteria at } 90 \mathrm{~min}}{\text { Number of bacteria at } 0 \mathrm{~min}} \times 100$.

that MSHA must be chromosomally encoded. $S$. dublin strain 2229 does not adhere to HeLa cells or to bovine brush borders or caecal epithelial cells (E. J. Manning, unpublished results).

\section{LD50 values after ip or iv injection}

To assess further the invasiveness of the mutants in mice, their virulence after ip and iv injection was determined. If the invasiveness of mutants M51 and M173 had been altered by the transposon insertion, their virulence after ip or iv injection, which bypasses the gut invasion step of pathogenesis, should have been more like that of the parent strain. However, there was still a $10^{4}-10^{5}$ difference between the LD50 values of the wild-type and mutant strains (table I). This suggests that the reduced virulence of the mutants for mice when administered by mouth was not due to reduced invasion of the gut.

\section{Serum resistance}

Measurements were made in vitro of the serum resistance of strain 2229, mutants M51 and M173, and the cured derivative 173/2. All strains were equally resistant to rabbit serum; they grew in a final serum concentration of $80 \%$. Each strain was slightly sensitive to bovine serum (table 2).

\section{Discussion}

Our virulence studies on $S$. dublin wild-type and mutant strains have shown that the $S$. dublin plasmid of mol. wt $46 \times 10^{6}$ is important for the pathogenicity of the organism. These results are in agreement with those of other workers (Jones et al., 1982; Terakado et al., 1983). However, the plasmid does not seem to affect the ability of the organism to cross the mouse gut wall, because loss of virulence in the mutants was unaffected by the route of inoculation. This contrasts with the role of the S. typhimurium plasmid in invasion of HeLa cells (Jones et al., 1982). The virulence of the cured derivative 173/2 was similar to that of mutants $\mathrm{M} 173$ and M51, indicating that the residual virulence of this cured derivative (and probably also of M51 and M173) is chromosomally-encoded.

The ip and and iv routes of inoculation are highly efficient methods of establishing infection with $S$. dublin strain 2229 in mice. It was not possible to calculate an LD50 value for strain 2229 but a dose of $<5 \mathrm{cfu}$ was always lethal (table 1 ). If only one or two organisms need to cross the gut wall to establish infection (Collins, 1972), it is perhaps not surprising that we have been unable to correlate virulence with adhesion to, or invasion of, intestinal cells and membranes. Indeed, invasion of the gut may be a passive process and an "invasive" organism may simply be one that can survive host defence processes once it has penetrated the gut wall.

The finding that each $S$. dublin strain tested showed mannose-sensitive, but not mannose-resistant, haemagglutinating activity indicated that MSHA is not plasmid encoded, and that MRHA is not involved in the virulence of S. dublin strain 2229 in mice. Tavendale et al. (1983) suggested that MSHA, and not MRHA, is necessary for the adhesion of $S$. typhimurium to HEp2 and HeLa cells in vitro. However, MSHA is not thought to be essential for infection (Duguid et al., 1976; Tavendale et al., 1983), therefore adhesion to cells in vitro may not be a good model for virulence in vivo. Although MRHA was not detected in strain 2229, c. $60 \%$ of all other $S$. dublin strains tested had MRHA activity against at least one species of erythrocyte (G. T. H. Brown and E. J. Manning, unpublished results). Thus strain 2229 differs in this respect from many other $S$. dublin isolates, and also from the $S$. typhimurium strains described by Jones and Richardson (1981).

Because our results suggested that the mutants had not lost their ability to cross the gut wall, it seemed possible that their reduced virulence might be due to diminished ability to resist host defences. One aspect of resistance to host defences is the ability of certain bacteria to resist the bactericidal action of normal serum (Taylor and Hughes, 1978) 
but the wild-type and mutant strains were equally resistant to rabbit and to bovine serum. The serum resistance of $S$. dublin strain 2229 must be chromosomally encoded, unlike that of some $E$. coli strains (Taylor and Hughes, 1978), because results obtained with strains 2229 and $173 / 2$ were similar. It is not known how well this in-vitro test relates to host defence mechanisms in vivo.

In conclusion this work has shown that in two

\section{REFERENCES}

Baird G D, Manning E J 1984 Molecular evidence for plasmid involvement in the virulence of Salmonella dublin. In: Priority aspects of Salmonellosis research, Commission of the European Communities (Publication EUR 9197EN), pp 147-151.

Birnboim H C, Doly J 1979 A rapid alkaline extraction procedure for screening recombinant plasmid DNA. Nucleic Acids Research 7:1513-1523.

Collins F M 1972 Salmonellosis in orally infected specific pathogen-free C57BL mice. Infection and Immunity 5:191198.

Duguid J P, Darekar M R, Wheater D W F 1976 Fimbriae and infectivity in Salmonella typhimurium. Journal of Medical Microbiology 9:459-473.

Hale T L, Sansonetti P J, Schad P A, Austin S, Formal S B 1983 Characterization of virulence plasmids and plasmid-associated outer membrane proteins in Shigella flexneri, Shigella sonnei and Escherichia coli. Infection and Immunity 40:340 350.

Jones G W, Rabert D K, Svinarich D M, Whitfield H J 1982 Association of adhesive, invasive and virulent phenotypes of Salmonella typhimurium with autonomous 60 -megadalton plasmids. Infection and Immunity 38:476-486.

Jones G W, Richardson L A 1981 The attachment to, and invasion of HeLa cells by Salmonella typhimurium: the contribution of mannose-sensitive and mannose-resistant haemagglutinating activities. Journal of General Microbiology 127:361-370. instances an insertion-mutation in the $46 \times 10^{6}$. mol. wt plasmid of $S$. dublin reduces virulence of the organism, but apparently not by affecting its ability to cross the gut wall. The possibility that the mutants can less easily resist host defences in vivo requires further investigation.

We are grateful to Mr P. Collins and Miss G. D. Pullinger for excellent technical assistance and to Mr G. T. H. Brown for help and advice with the haemagglutination assays.

Jones G W, Rutter J M 1974 The association of K88 antigen with haemagglutinating activity in porcine strains of Escherichia coli. Journal of General Microbiology 84:135-144.

Manning E J, Baird G D, Jones P W 1984 Possible plasmid involvement in the virulence of Salmonella dublin. Biochemical Society Transactions 12:847-848.

Reed L J, Muench H 1938 A simple method of estimating fifty per cent end points. American Journal of Hygiene 27:493497.

Rodriguez R L, Bolivar F, Goodman H M, Boyer H W and Betlach M 1976 Construction and characterization of cloning vehicles. In: Nierlich D P, Rutter W J, Fox C F (eds). Molecular mechanisms in the control of gene expression. Academic Press. New York, pp 471-477.

Tavendale A, Jardine C K H, Old D C, Duguid J P 1983 Haemagglutinins and adhesion of Salmonella typhimurium to HEp2 and HeLa cells. Journal of Medical Microbiology 16:371-380.

Taylor P W, Hughes C 1978 Plasmid carriage and the serum sensitivity of enterobacteria. Infection and Immunity 22:10 17.

Taylor P W, Roberts A P, Gower P E 1972. Evaluation of a technique for the estimation of serum bactericidal activity against Gram-negative organisms. Medical Laboratory Technology 29:272-279.

Terakado N, Sekizaki T, Hashimoto K, Naitoh S 1983. Correlation between the presence of a fifty Megadalton plasmid in Salmonella dublin and virulence for mice. Infection and Immunity 41:443-444. 